\title{
Spatial Distribution of Soil Organic Matter and Soil Organic Carbon Stocks in Semi-Arid Area of Northeastern Syria
}

\author{
Hussam Hag Husein ${ }^{1 *}$, Mohammad Mousa², Wahib Sahwan1, Rupert Bäumler¹, Bernhard Lucke1 \\ ${ }^{1}$ Institute of Geography and Soil Science, FAU Erlangen Nuremberg University, Erlangen, Germany \\ ${ }^{2}$ General Commission for Scientific Agriculture Research, Al Raqqa, Syria \\ Email: ^hussam_syr1@yahoo.com
}

How to cite this paper: Husein, H.H., Mousa, M., Sahwan, W., Bäumler, R. and Lucke, B. (2019) Spatial Distribution of Soil Organic Matter and Soil Organic Carbon Stocks in Semi-Arid Area of Northeastern Syria. Natural Resources, 10, 415-432. https://doi.org/10.4236/nr.2019.1012028

Received: November 14, 2019 Accepted: December 23, 2019 Published: December 26, 2019

\section{Copyright $\odot 2019$ by author(s) and} Scientific Research Publishing Inc. This work is licensed under the Creative Commons Attribution International License (CC BY 4.0).

http://creativecommons.org/licenses/by/4.0/

(c) (i) Open Access

\begin{abstract}
Although soil organic matter (SOM) forms a small portion of the soil body. Nevertheless, it is the most important component of the soil ecosystem, as well as of the carbon global cycle. In the semi-arid environment, there has been little research on the spatial distribution of SOM and soil organic carbon (SOC) stock. In this study, stratified random samples of total 30 soils were collected from two different soil depth (topsoil, subsoil) of Al Balikh plain and used for mapping the spatial variability of SOC and to estimating the SOC stock. The result showed that the values were relatively homogenate, with the normal decreasing trend with increasing the depth. The standard deviation (Std. D) for both SOC and SOC stock indicates homogeneous and absence of outliers values, whereas the coefficient of variation (C.V) indicates non-dispersion and clustering of values around the average. SOC was $0.38 \%$, $0.17 \%$ in topsoil and subsoil respectively; the corresponding averages of SOC stock were $1.23 \mathrm{~kg} \cdot \mathrm{m}^{-2}$ and $1.14 \mathrm{~kg} \cdot \mathrm{m}^{-2}$ respectively, these values reflecting typical characteristics of poor SOC semi-arid soil. The correlation between SOC and SOC stock was $\left(\mathrm{R}^{2}=0.996, \mathrm{p}<0.001\right)$ in topsoil and it was $\left(\mathrm{R}^{2}=\right.$ $0.941, \mathrm{p}<0.001)$ for subsoil. The semivariograms were indicated that both SOC and SOC stock were best fitted to the exponential model. Nugget, range, and sill were equal to $0.002,0.036$, and 0.044 , respectively for SOC in topsoil, and $0.014,0.071$, and 0.081 , for SOC in the subsoil. For SOC stock, it was 0.0, 0.036 , and 0.0508 , respectively in topsoil. In the subsoil, the values were $0.1899,0.086$, and 4.159 , respectively. SOC and SCO stock in both two layers are shown a strong spatial dependence, for which were 4.3, 17.2 for SOC in topsoil and subsoil respectively, and 0.0, 4.5 for SOC stock in topsoil and subsoil respectively, thus, which can be attributed to intrinsic factors.
\end{abstract}




\section{Keywords}

Soil Organic Carbon Stock, Semi-Arid, Semivariogram, Exponential Model, Flood Plain

\section{Introduction}

There is great interest in recognizing the soil system as the most important long-term organic carbon (OC) reservoir in terrestrial ecosystems contributing to global climate change [1]-[6]. SOM which is a major source of OC is composed of a variety of plant and animal residues in different stages of decomposition [7]. SOC content is indispensable for the assessment of SOCS, and its importance also has been emphasized by [8] [9] [10] and others, as an important role in the agricultural productivity and soil sustainability and quality [11] [12] [13]. The sources and the decomposing factors of SOM vary in space and time [14]. Also, it is sensitive to environmental changes [15] [16]. Whereas, several factors such as soil type, climate, terrain, hydrology, land use, geology, etc. affect their distribution [17]. Organic matter often binds to fine particles, particularly clay [2], and the high amount of SOM tends to be limited to the soil surface, probably at a depth of 5 to $10 \mathrm{~cm}$ [18]. For this reason, most soil studies focus on topsoil, not on the whole soil profile. In fact, a considerable fraction of the total soil organic carbon (SOC) stock is known to be stored in the subsoil [19] [20], whereas a substantial amounts $(27 \%-77 \%)$ of SOC could occur at depths greater than $20 \mathrm{~cm}$ [21]. Therefore, it should not be neglected in an ecosystem service context [22].

However, the reliable assessment and monitoring of SOCS is a key importance for soil conservation as well as in mitigation strategies for increased atmospheric carbon [23]; as such, small changes in the soil carbon storage may significantly affect the $\left(\mathrm{CO}_{2}\right)$ concentration of the atmosphere [24]. This situation increases the importance of SOM in a semi-arid region due to its extensive extension and its constant exposure to extreme climatic conditions, for all that there is little research examining SOC in these areas. The semi-arid lands are areas with an aridity index range from 0.2 to 0.5 [25] [26], vulnerable soil, and either desertified or prone to desertification. It is still questionable how much SOC is stored in the arid soils, as the SOC pool tends to decrease exponentially with temperature [27], and consequently, it has soils of low OC content (less than 1\%) [28] [29], which can lead to progressive degradation of their quality and productivity [30]. Nevertheless, these areas might play a key role in the mitigation of climate change effects by reducing the rate of enrichment of atmospheric $\left(\mathrm{CO}_{2}\right)$ [29]. Spatial representation of the SOC is considered very essential for regional planning, soil management, soil evaluation, and agriculture practices [31]. Remote sensing and GIS play vital roles in the preparation of spatial illustration [32]. During the last decade, various digital soil map techniques were used to ex- 
amined the accuracy of SOC prediction by comparing different methods such as linear regression, ordinary kriging, co-kriging, regression kriging, inverse distance weighted, splines etc. [23] [33] [34] [35] [36]. Nevertheless, there is no particular method, which predicts the SOC with the best accuracy; all the deterministic interpolation methods where results tend to oversimplify the reality [37].

Many geostatistics methods have used the location samples for soil mapping [38] [39] [40] [41] [42]. However, Geostatistics has an ability to distinguish the continuous nature of SOC and is able to detect random variations during modeling [43], and the spatial autocorrelation is considered to interpolate into a continuous surface from sample points [44]. In the east of Syria, arid and semi-arid lands are widely dominated, with annual precipitation ranging from $200 \mathrm{~mm}$ in mid-east to less than $50 \mathrm{~mm}$ in the south-east, represents $\mathrm{Al}$ Badia ecosystem, which is a transition zone between desert in the east and south and Mediterranean ecosystem in the west. The soils in this rainfed area are characterized by their low content of organic matter makes topsoil fragile and may experience degradation, desertification, and wind erosion. However, the SOC, which is a key for crop production here, has not been widely studied; it is believed that the improvement of crop production in these areas should be associated with the sustainability of soil productivity if it cannot be improved and increased [45].

The objectives of this study were to evaluate the stature of the soil organic carbon content in the study area, to study the spatial variability of SOM content in this intensively cropped land, and to estimate the OC stock within such kind of semi-arid land.

\section{Material and Methods}

\subsection{Study Area}

The study area is located about $50 \mathrm{~km}$ northeast of the city of Ar-Raqqa, The total area is $15274.97 \mathrm{ha}$, between of $39^{\circ} 02^{\prime} 10.0^{\prime \prime}-38^{\circ} 47^{\prime} 10.0^{\prime \prime} \mathrm{N}$, and $36^{\circ} 08^{\prime} 10.0^{\prime \prime}$ $36^{\circ} 00^{\prime} 10.0^{\prime \prime} \mathrm{E}$, in a deposited fan of Al-Balikh river with elevation about 290 (a. m. s. l) (Figure 1).

The site represents a flat region of a reclaimed agricultural field in the east of Syria [46]; hence, there is no considerable topographic relief within the area under consideration [47]. The area submitted to steppe climate [48], which is semi-arid climate with an average annual rainfall of less than $200 \mathrm{~mm}$ and hot dray summer session with annual mean temperature $17^{\circ} \mathrm{C}$ where evaporation reaches up to $14 \mathrm{~mm} / \mathrm{d}$. For the most part, somewhat poorly drained soils originated from alluvial and proluvial Quaternary depositions, in which Aridisols of Gypsids and Calsids suborders are predominate [47]. Many investigations addressed this area before constructing a complete irrigation and drainage system, e.g. [49], Nedeco from Netherlands in 1963; Sir Alexander Gibb and Partners from England in 1966; and Sogeria from France in 1976 [46]. Shallow water tables exist all year between 1 and $10 \mathrm{~m}$. From a geological point of view, the 

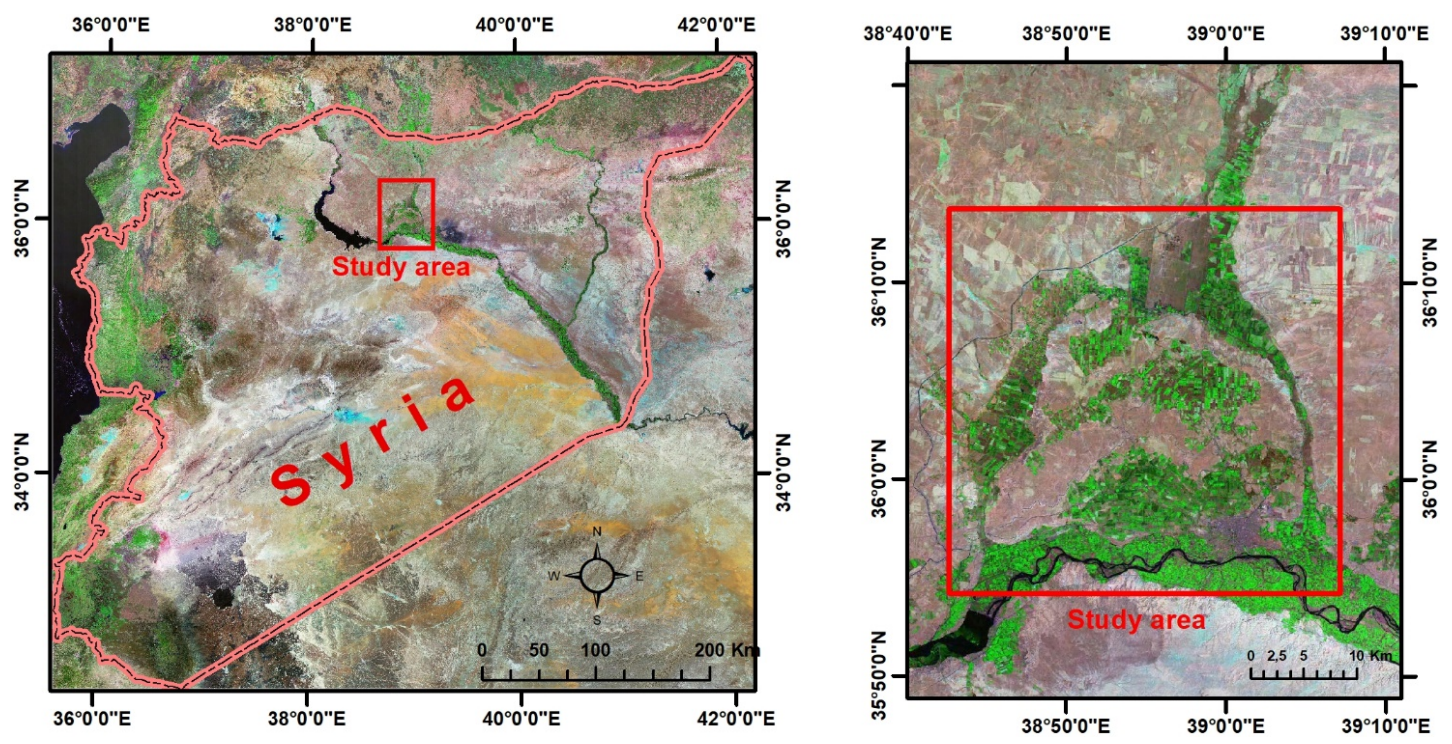

Figure 1. Location of Al Balikh plain north east Syria. Sources: Landsat ETM+ (April 2012 path 172, raw 35).

area is composed of Quaternary alluvium (loam, sandy loams, gravel, mud, pebbles, and sands) [50]. Land reclamation project area started in 1970; where irrigation system, drainage networks as well as leveling have been conducting and the area has entered into investing since 1973, meanly cotton, in rotation with wheat are often planted [46].

\subsection{Soil Sampling and Chemical Analysis}

Spatial distribution of SOM requires determination of soil OC concentrations, and for determination of soil OC concentrations, additional parameters of bulk densities (BD), stone contents, and soil depth are required [51].

Soil sampling was executed using a Global Position System (GPS) in order to restrict sampling points in the field and to record longitude, latitude, and elevation of each point. BD was measured for topsoil $(0-30 \mathrm{~cm})$ and subsoil $(30-60)$ by using the method of [52].

Soil samples were taken from well-distributed 30 soil profiles; then the samples were air-dried and ground to pass through $2 \mathrm{~mm}$ sieve prior to analysis. Samples were analyzed for carbonates (subtraction method, after removing OC at $550^{\circ} \mathrm{C}$ ). OC content in fine earth was determined in duplicated samples using the potassium dichromate oxidation [53], and soil organic carbon was calculated using the Equation (1) [54]:

$$
\mathrm{SOM}=1.72 \times \mathrm{SOM}
$$

Percentage of coarse fragments was assessed by visual estimates (by comparing with area charts). The SOC stocks in topsoil and subsoil were calculated from SOC concentrations and BD. To avoid overestimation of SOC stocks, the fraction of coarse fragments (mineral particles $<2 \mathrm{~mm}$ ) was considered, the SOCS was calculated after [55]:

$$
\text { SOCS }=d \times B D \times\left(C_{\text {tot }}-C_{\min }\right) \times C F_{s t}
$$


where: SOCS is SOCS $\left[\mathrm{kg} / \mathrm{m}^{2}\right], C_{\text {tot }}$ and $C_{\min }$ are total and mineral carbon $\left[\mathrm{g} \cdot \mathrm{g}^{-1}\right.$, $d$ is depth of horizon/depth class [m], $B D$ is bulk density $\left[\mathrm{kg} / \mathrm{m}^{3}\right], C F_{s t}$ is correction factor for coarse fragments content $(1-(\%$ gravel $+\%$ stones $) / 100)$.

\subsection{Statistical and Geostatistical Analysis}

The statistical analyses of extreme maximum and minimum values, mean, Standard deviation, Kurtosis, Skewness, Coefficient of Variation, were conducted to assess the pattern of distribution of data frequency and to find out the relationship between environmental and soil variable which is not always liner and it is usually complex. Kriging is a geostatistical method that is very popular nowadays [56] [57], commonly used to interpolate soil property datasets from discrete points to a spatially continuous surface [58] [59]. Kriging and its derivative methods are considered more accurate and stable for prediction of SOC [60] [61]. Ordinary Kriging (OK) often gives better interpolation for estimating values at unmeasured locations [34] [38] [62]-[67]. Moreover, it is the superior method for interpolation of SOC spatial distribution [68]; therefore, the OK was used to generate maps of SOM distribution. Kriging estimate $z^{*}\left(x_{0}\right)$ and error estimation variance $\sigma_{k}^{2}\left(x_{0}\right)$ at any point $x_{0}$, were calculated as follows [69]:

$$
\begin{gathered}
z^{*}\left(x_{0}\right)=\sum_{k=0}^{n} \lambda_{i} Z\left(x^{i}\right) \\
\sigma_{k}^{2}\left(x_{0}\right)=\mu+\sum_{k=0}^{n} \lambda_{i} \gamma\left(x_{0}-x_{i}\right)
\end{gathered}
$$

where $\lambda_{i}$ are the weights $\mu$ is the lag range constant; and $\gamma\left(x_{0}-x_{i}\right)$ is the semivariogram value corresponding to the distance between $x_{0}$ and $x_{i}$ [70] [71].

Semivariograms were used to quantify the spatial variation of each regionalized geostatistical variable and to determine the spatial continuity and distribution structure of OM. Because it is simply enumerates the relationship between the degree of similarity between the two measurements of some variable $Z\left(x_{i}\right)$ separated by distance $h$, which is termed the lag [72] [73], as follows:

$$
\gamma(h)=\frac{1}{2 N(h)} \sum_{i=1}^{N(h)}\left[z\left(x_{i}\right)-z\left(x_{i}+h\right)\right]^{2}
$$

where: $\gamma(h)$ are the samivariograms, $z\left(x_{i}\right)$ and $z\left(x_{i}+h\right)$ are experimental measures of any two points separated by the vector $h$, and $N(h)$ is the number of pairs separated by a lag distance $h, Z\left(x_{i}\right)$, and $Z\left(x_{i}+h\right)$ are values of $Z$ at positions $x_{i}$ and $x_{i}+h$ [74].

The semivariograms obtained from the data were fitted to produce geostatistical parameters, including nugget variance $\left(C_{0}\right)$, structured variance $\left(C_{1}\right)$, and sill variance $\left(C_{0}+C_{1}\right)$. The nugget/sill ratio (spatial dependencies) $C_{0} /\left(C_{0}+C_{1}\right)$, was calculated to imitate the spatial autocorrelation of the values. The spatially dependent variables were classified as: strongly spatially dependent if the ratio was $\leq 25 \%$, mid-spatial-dependent if the ratio was $25 \%-75 \%$ and weakly spatially dependent if the ration was $\geq 75 \%$ [75] [76] [77]. Parameters obtained from the semivariograms were used to produce thematic maps of the SOM in topsoil and subsoil, [69]: 


$$
Z^{*}\left(x_{0}\right)=\sum_{i=1}^{n} \lambda_{i} \cdot Z\left(x_{i}\right)
$$

where: $Z^{*}\left(x_{0}\right)$ - interpolated value of variable $Z$ at location $x_{0}, Z\left(x_{i}\right)$-values measured at location $x_{i}, \lambda_{i}$ - weighed coefficients calculated on the basis of the semivariogram when:

$$
\sum_{i=1}^{n} \lambda_{i}=1
$$

The weights, calculated in this way, make it possible to obtain non-biased interpolated values, i.e., the expected value:

$$
E\left[Z^{*}\left(x_{0}\right)-Z\left(x_{0}\right)\right]=0
$$

The estimated variance:

$$
\operatorname{Var}\left[Z^{*}\left(x_{0}\right)-Z\left(x_{0}\right)\right]=\operatorname{minimu}
$$

\section{Results and Discussion}

The field measurement and laboratory analyses across 30 sites within two descending soil layers are presented in Table 1 . In general, the soil was similar to other Euphrates soil, in terms of topsoil partly eroded by aeolian erosion, although, the soil showed differing distinctly, in terms of organic matter content [78], in Table 1.

Soil Thickness is moderate to somewhat deep, ranging from $30 \mathrm{~cm}$ to more than $90 \mathrm{~cm}$, this is relatively thicker than the typical soil of the area, it can be explained by long and continues irrigated agriculture and deep plowing application. Another important phenomenon is raising of soil water table even to $50 \mathrm{~cm}$ soon after profile excavating (Figure 2).

Table 1. Field measurement and laboratory analyses for the soil of Al Balikh plain.

\begin{tabular}{ccccccccccc}
\hline \multirow{3}{*}{$\begin{array}{c}\text { Soil } \\
\text { profile }\end{array}$} & $\begin{array}{c}\text { Depth } \\
\mathrm{cm}\end{array}$ & $\begin{array}{c}\text { B.D. } \\
\mathrm{kg} / \mathrm{m}^{3}\end{array}$ & Clay \% & $\begin{array}{c}\text { SOC } \\
\%\end{array}$ & $\begin{array}{c}\text { SOCS } \\
\mathrm{kg} / \mathrm{m}^{2}\end{array}$ & $\begin{array}{c}\text { Depth } \\
\mathrm{cm}\end{array}$ & $\begin{array}{c}\text { B.D. } \\
\mathrm{kg} / \mathrm{m}^{3}\end{array}$ & $\begin{array}{c}\text { Clay } \\
\%\end{array}$ & $\begin{array}{c}\text { SOC } \\
\%\end{array}$ & $\begin{array}{c}\text { SOCS } \\
\mathrm{kg} / \mathrm{m}^{2}\end{array}$ \\
\hline P1 & 30 & 1.2 & 34 & 0.40 & 1.27 & 50 & 1.4 & 20 & $\mathrm{~T}^{*}$ & N.D \\
P2 & 15 & 1.29 & 26 & 0.40 & 1.36 & 50 & 1.32 & 36 & 0.40 & 2.3 \\
P3 & 15 & 1.21 & 36 & 0.29 & 0.91 & 50 & 1.31 & 36 & 0.79 & 7.02 \\
P4 & 20 & 1.23 & 36 & 0.29 & 0.93 & 70 & 1.33 & 20 & $\mathrm{~T}$ & N.D \\
P5 & 25 & 1.3 & 10 & 0.29 & 0.98 & 40 & 1.3 & 10 & $\mathrm{~T}$ & N.D \\
P6 & 30 & 1.23 & 40 & 0.87 & 2.78 & 30 & 1.36 & 10 & $\mathrm{~T}$ & N.D \\
P7 & 50 & 1.3 & 28 & 0.63 & 2.15 & 50 & 1.4 & 10 & $\mathrm{~T}$ & N.D \\
P8 & 30 & 1.31 & 44 & 0.69 & 2.37 & 90 & 1.39 & 20 & $\mathrm{~T}$ & N.D \\
P9 & 15 & 1.2 & 10 & 0.06 & 0.18 & 50 & 1.27 & 20 & $\mathrm{~T}$ & N.D \\
P10 & 15 & 1.21 & 10 & 0.40 & 1.28 & 80 & 1.38 & 44 & $\mathrm{~T}$ & N.D \\
P11 & 30 & 1.26 & 30 & 0.12 & 0.38 & 105 & 1.3 & 10 & $\mathrm{~T}$ & N.D \\
\hline
\end{tabular}




\section{Continued}

\begin{tabular}{ccccccccccc}
\hline P12 & 10 & 1.25 & 34 & 0.12 & 0.38 & 80 & 1.36 & 46 & $\mathrm{~T}$ & $\mathrm{~N} . \mathrm{D}$ \\
P13 & 20 & 1.2 & 20 & 0.52 & 1.63 & 53 & 1.33 & 36 & 0.70 & 4.4 \\
P14 & 35 & 1.23 & 44 & 0.52 & 1.67 & 35 & 1.21 & 10 & 0.78 & 2.96 \\
P15 & 25 & 1.3 & 43 & 0.56 & 1.92 & 55 & 1.4 & 12 & $\mathrm{~T}$ & $\mathrm{~N} . \mathrm{D}$ \\
P16 & 20 & 1.34 & 42 & 0.51 & 1.78 & 50 & 1.36 & 44 & 0.19 & 1.19 \\
P17 & 30 & 1.32 & 42 & 0.06 & 0.19 & 70 & 1.47 & 46 & $\mathrm{~T}$ & $\mathrm{~N} . \mathrm{D}$ \\
P18 & 32 & 1.21 & 36 & 0.45 & 1.43 & 93 & 1.29 & 14 & $\mathrm{~T}$ & $\mathrm{~N} . \mathrm{D}$ \\
P19 & 23 & 1.18 & 44 & 0.23 & 0.70 & 70 & 1.53 & 34 & $\mathrm{~T}$ & $\mathrm{~N} . \mathrm{D}$ \\
P20 & 25 & 1.24 & 36 & 0.40 & 1.28 & 50 & 1.29 & 40 & 0.39 & 2.25 \\
P21 & 30 & 1.21 & 34 & 0.17 & 0.54 & 30 & 1.31 & 20 & $\mathrm{~T}$ & $\mathrm{~N} . \mathrm{D}$ \\
P22 & 35 & 1.21 & 38 & 0.51 & 1.61 & 50 & 1.29 & 28 & $\mathrm{~T}$ & $\mathrm{~N} . \mathrm{D}$ \\
P23 & 3 & 1.17 & 44 & 0.62 & 1.90 & 40 & 1.54 & 20 & $\mathrm{~T}$ & $\mathrm{~N} . \mathrm{D}$ \\
P24 & 25 & 1.18 & 38 & 0.17 & 0.52 & 70 & 1.53 & 10 & $\mathrm{~T}$ & $\mathrm{~N} . \mathrm{D}$ \\
P25 & 18 & 1.27 & 36 & 0.12 & 0.38 & 50 & 1.34 & 14 & 0.10 & 0.59 \\
P26 & 18 & 1.2 & 22 & 0.45 & 1.42 & 50 & 1.36 & 40 & 0.10 & 0.59 \\
P27 & 30 & 1.22 & 34 & 0.34 & 1.08 & 90 & 1.32 & 42 & 0.29 & 3.11 \\
P28 & 20 & 1.22 & 40 & 0.28 & 0.90 & 80 & 1.24 & 48 & 0.58 & 5.2 \\
P29 & 15 & 1.24 & 24 & 0.40 & 1.31 & 55 & 1.33 & 38 & 0.50 & 3.26 \\
P30 & 30 & 1.21 & 30 & 0.56 & 1.78 & 50 & 1.37 & 40 & 0.19 & 1.198 \\
\hline & & & & & & & & & & \\
\hline
\end{tabular}

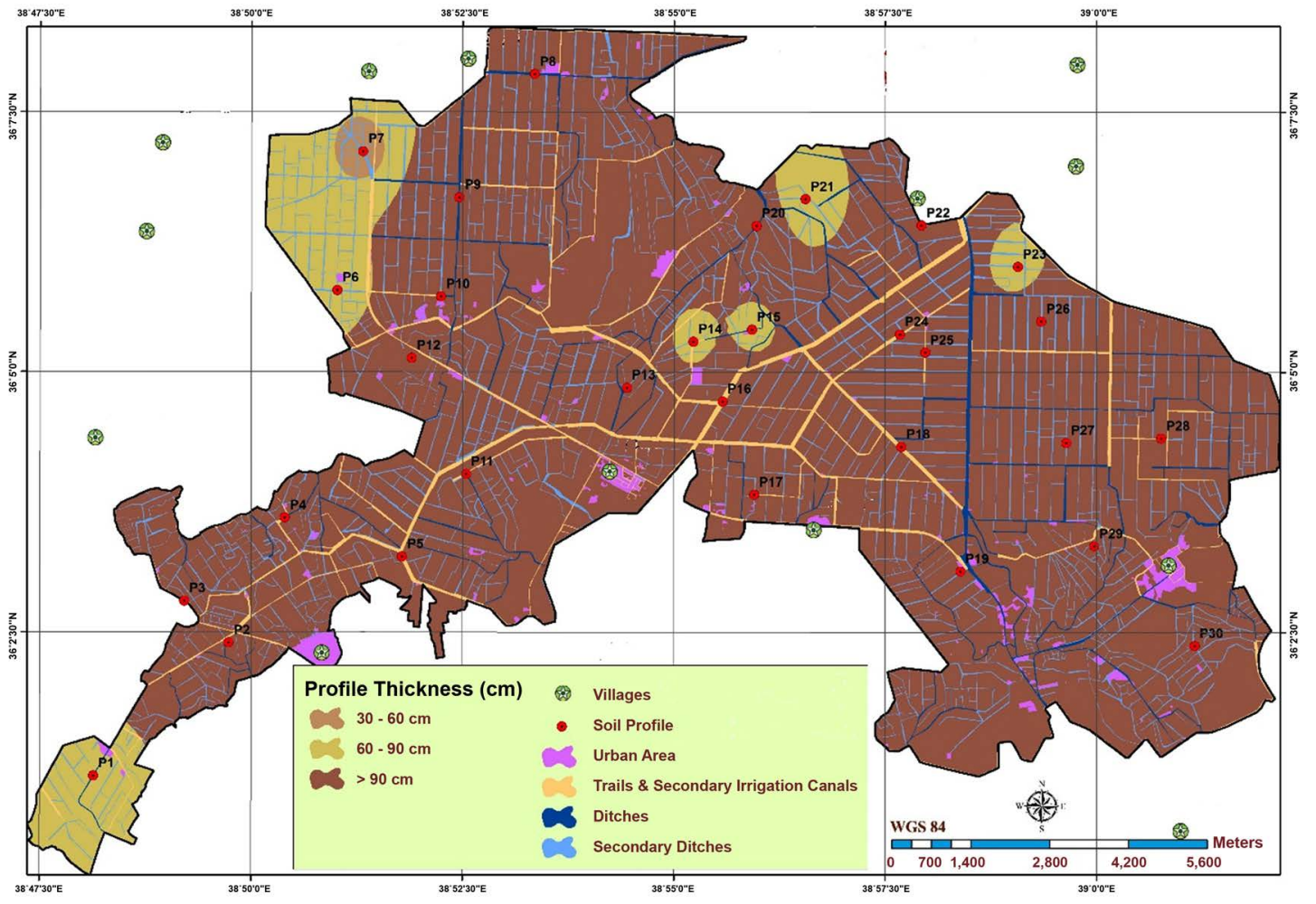

Figure 2. Soil thickness $(\mathrm{cm})$ in the study area. 
Soil clay content is moderate, and there is not much difference between the clay content in top and subsoil, the average for tops soil is $33 \%$ and for subsoil is $27 \%$, (Figure 3).

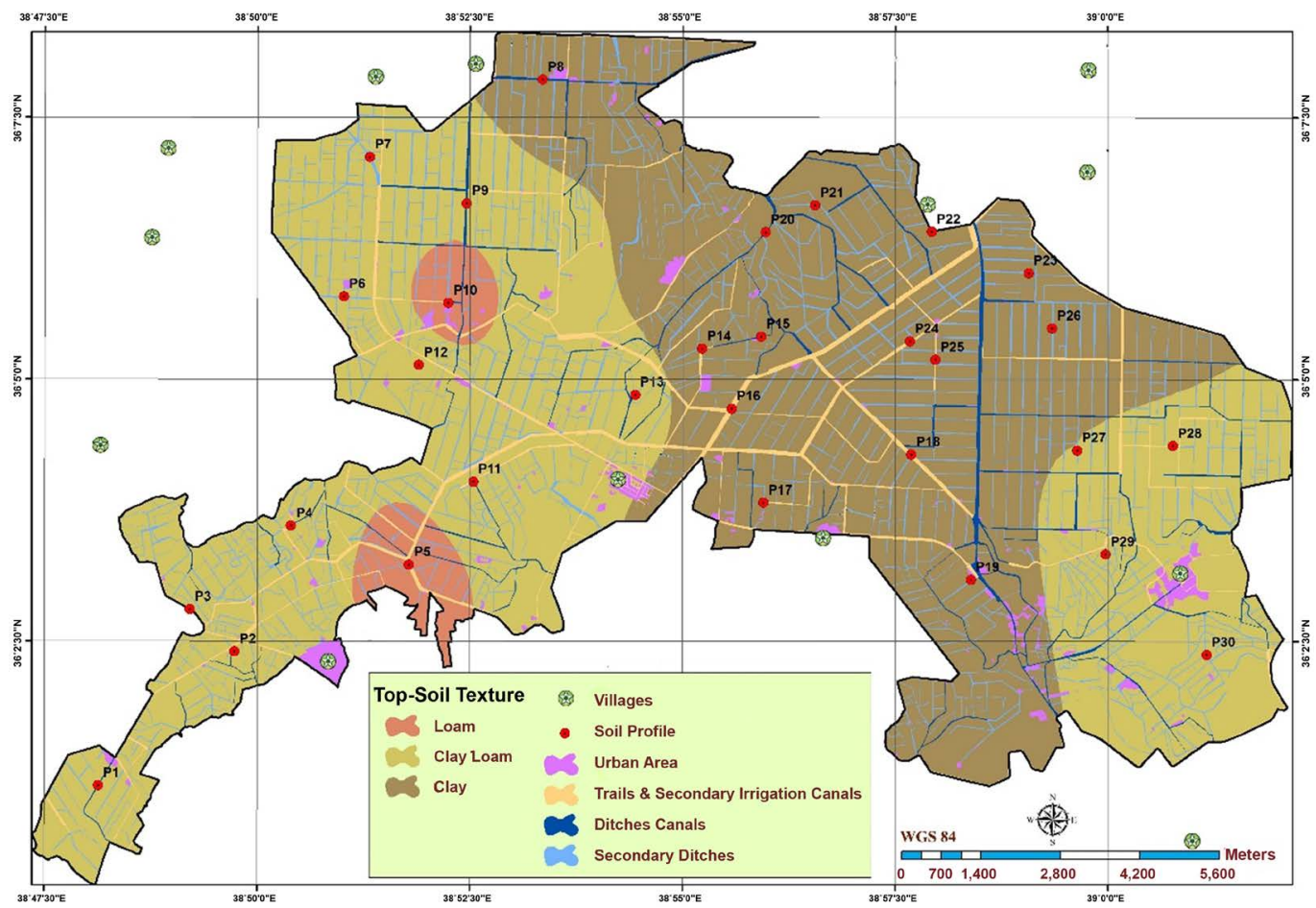

(a)

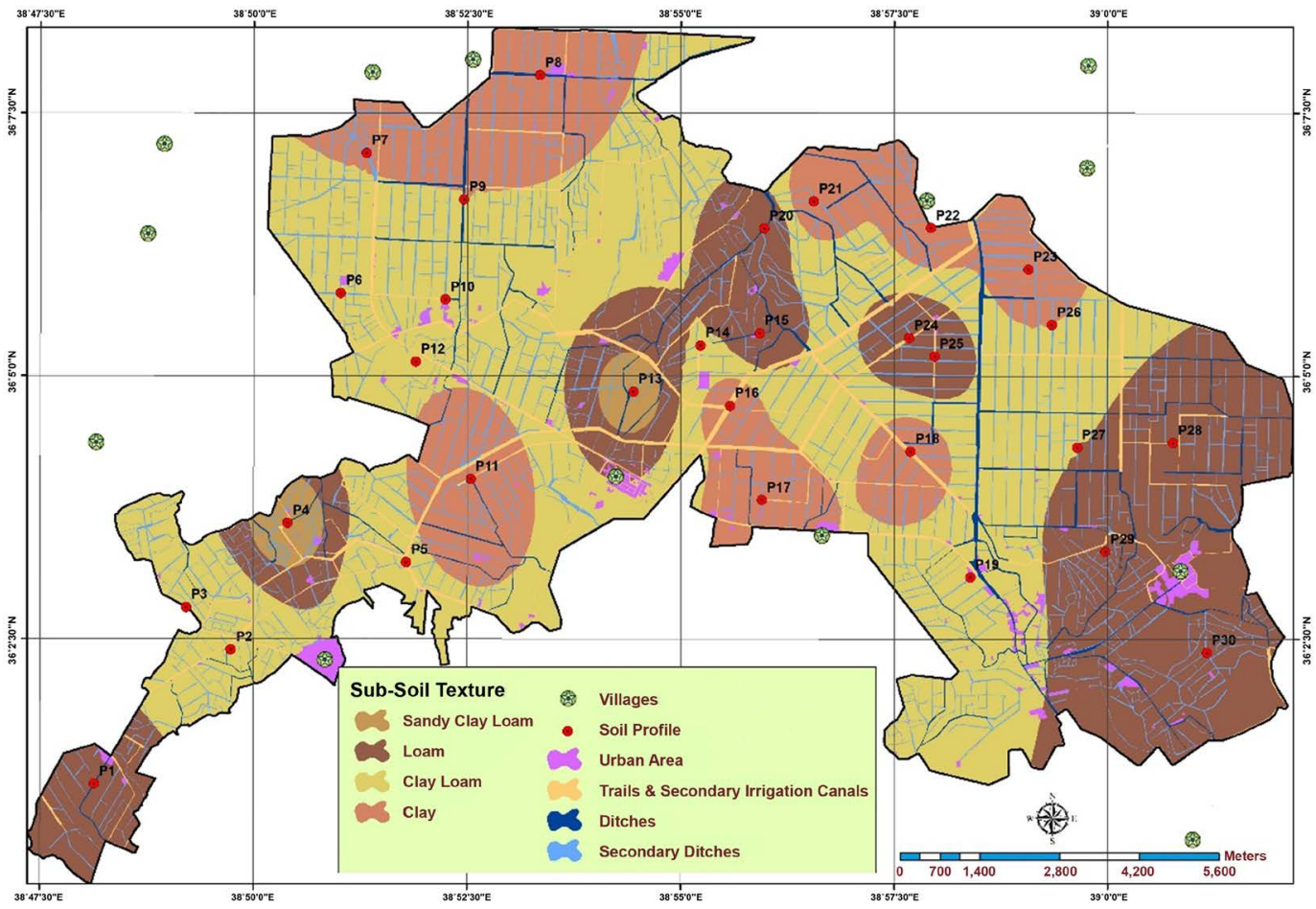

(b)

Figure 3. Spatial distribution of soil texture in topsoil (a) and subsoil (b). 
The statistical analyses of SOM and SOCS are presented in Table 2, where SOC exhibited large variations between the two soil strata, ranging from $0.06 \%$ $0.87 \%$ with an average of $0.38 \%$ in topsoil, and from $0.01 \%-0.79 \%$ with an average of $0.17 \%$ in the subsoil. The corresponding average of SOCS was 1.23 $\mathrm{kg} \cdot \mathrm{m}^{-2}$ and $1.14 \mathrm{~kg} \cdot \mathrm{m}^{-2}$ respectively. Thus, the soil can be termed as a poor to very poor of SOM and SOCS within both top- and subsoil, this is typical for semi-arid soil, (Figure 4).

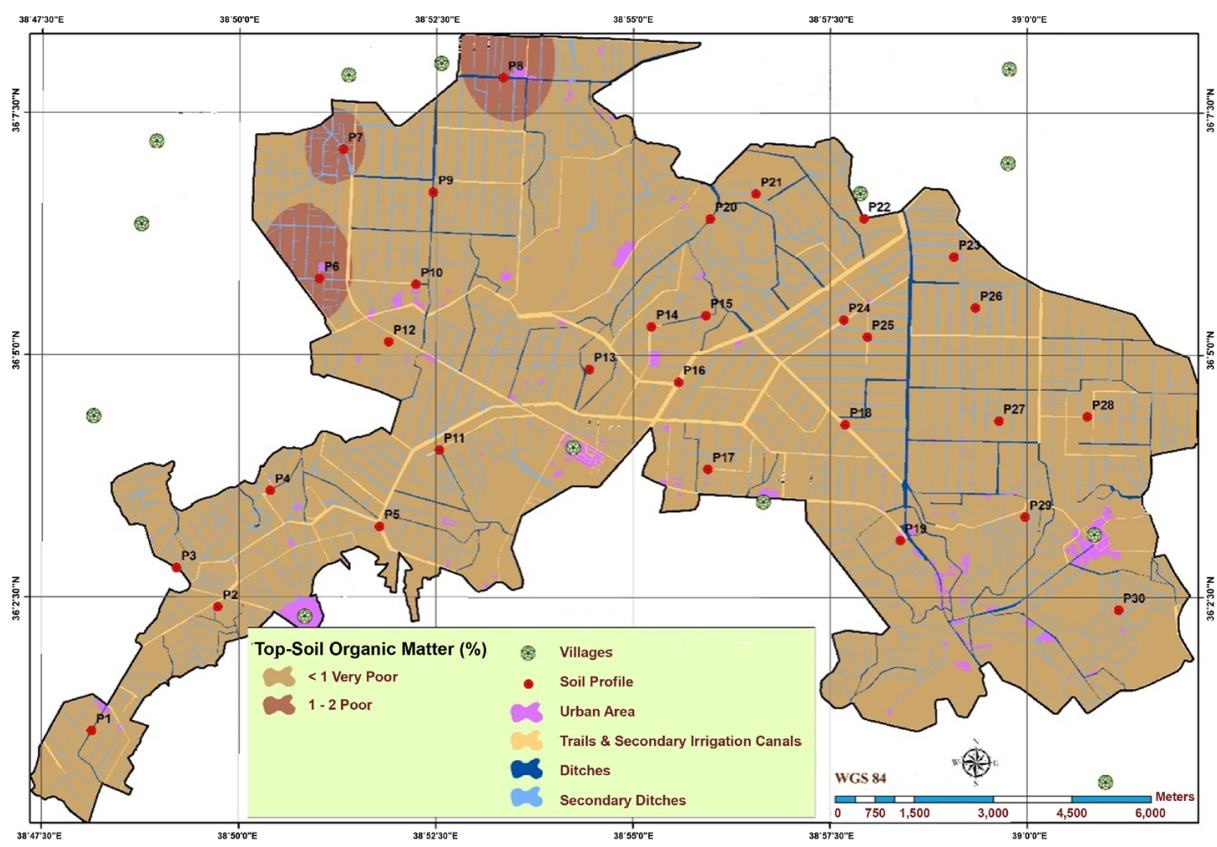

(a)

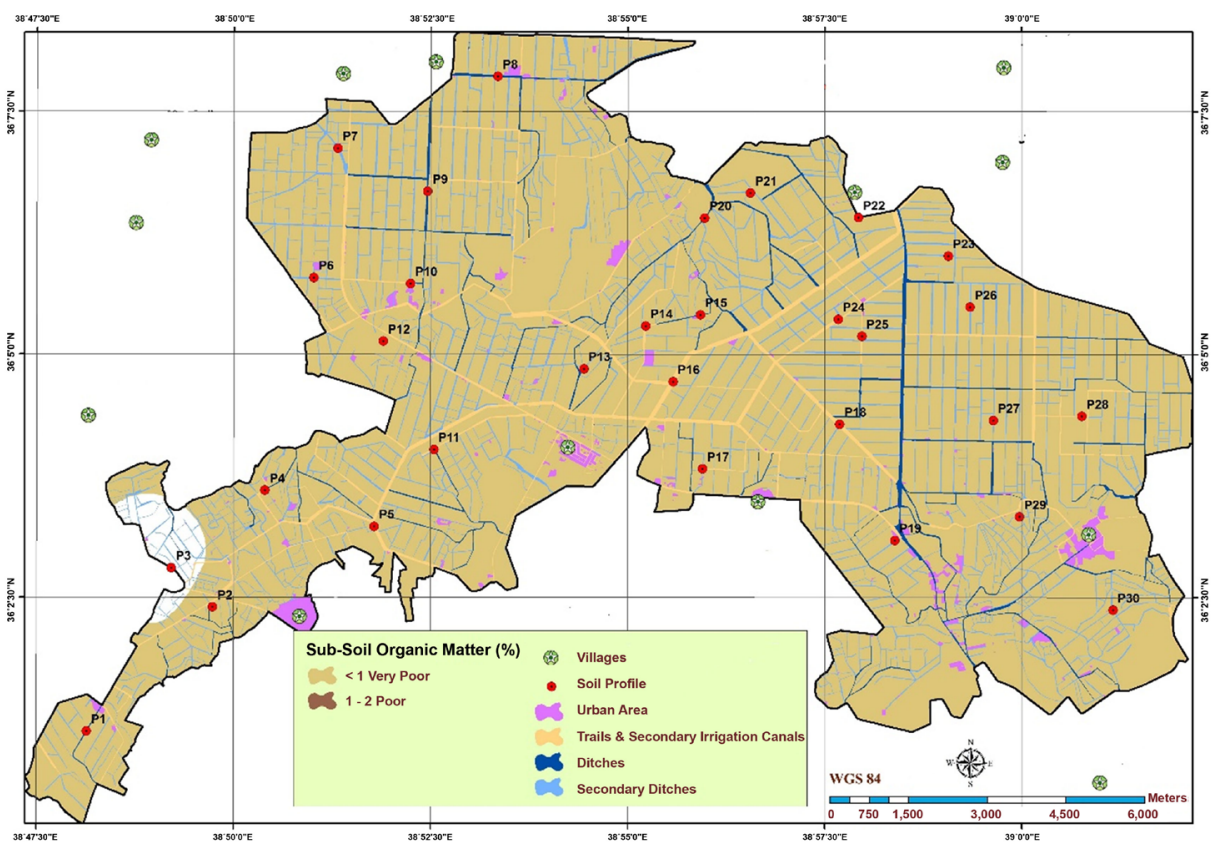

(b)

Figure 4. Spatial Distribution of Soil Organic Matter content in topsoil (a) and subsoil (b). 
Table 2. Summary statistics of the SOC and SOC stock within the soil of Al Balikh plain $(\mathrm{n}=30)$.

\begin{tabular}{|c|c|c|c|c|c|c|c|c|c|c|c|c|}
\hline \multirow{2}{*}{\multicolumn{2}{|c|}{ Variable }} & \multirow{2}{*}{ Min. } & \multirow{2}{*}{ Max. } & \multirow{2}{*}{$\begin{array}{c}\text { Mean } \\
\bar{x} \quad \pm t_{a, 0.05}\end{array}$} & \multirow{2}{*}{ Median } & \multirow{2}{*}{ Std. D. } & \multirow{2}{*}{ Skewness } & \multirow{2}{*}{ Kurtosis } & \multicolumn{2}{|c|}{ Quartile } & \multirow{2}{*}{ CV } & \multirow{2}{*}{$\begin{array}{c}\text { Pearson Correlation } \\
\text { Coefficients } \\
\text { (SOC, SOC) }\end{array}$} \\
\hline & & & & & & & & & 1.St. & 3.St. & & \\
\hline \multirow{2}{*}{ SOC (\%) } & Topsoil & 0.06 & 0.87 & $0.38 \pm 0.09$ & 0.4 & 0.20 & 0.20 & 2.54 & 0.22 & 0.51 & 0.52 & 0.996 \\
\hline & Subsoil & 0.01 & 0.79 & $0.17 \pm 0.09$ & 0.01 & 0.25 & 1.39 & 3.43 & 0.01 & 0.29 & 1.47 & 0.94 \\
\hline \multirow{2}{*}{$\begin{array}{l}\text { SOCS } \\
\mathrm{kg} / \mathrm{m}^{2}\end{array}$} & Topsoil & 0.18 & 2.78 & $1.23 \pm 0.09$ & 1.27 & 0.66 & 0.24 & 2.49 & 0.69 & 1.66 & 0.53 & 0.996 \\
\hline & Subsoil & 0.01 & 7.02 & $1.14 \pm 0.09$ & 0.01 & 1.85 & 1.66 & 4.38 & 0.01 & 2.25 & 1.62 & 0.94 \\
\hline
\end{tabular}

However, since arid and semi-arid land accounts for about 55\% of the total Syrian land, which is one of the fragile ecosystems and most sensitive to climate change, it is therefore obvious that its SOCS, which is already too low to be strong affected by climate change.

SOC showed a normal decreasing trend with increasing the depth. The higher of SOC in topsoil has been associated with the growth of root systems [79] and active soil microbial [80] [81], and with the quantity of above Stubble of harvested crops and biomass addition on the soil surface [82] [83] [84].

These cause a greater impact on the surface soil layer than on the deeper layers and can homogenize the spatial distribution of SOC in topsoil. In contrary, the preferential transport of SOC via cracks after dry periods could further increase the heterogeneity of SOC in the subsoil, this is can explain the high SOC stock in the subsoil of some profiles, e. g. P3 and P28. The standard deviation (Std. D) for both SOC and SOC stock indicates homogeneous and absence of outliers values, this is enhanced by the low (C.V), which indicates non-dispersion, and clustering of values around the average.

The relationship between SOM and SOC stock were statistically investigated (Pearson Correlation Coefficients); SOC stock in both top and subsoils was highly correlated with SOM, the correlation within topsoil was $\left(\mathrm{R}^{2}=0.996, \mathrm{p}<\right.$ $0.001)$ and it was $\left(\mathrm{R}^{2}=0.941, \mathrm{p}<0.001\right)$ for subsoil.

As known, demonstration of variation requires a normal distribution of data; otherwise, the proportional effect will occur. Skewness and kurtosis coefficients were used to describe the shape and flatness of data distribution respectively. Table 3, showed high kurtosis (leptokurtic), due to data concentrated around the average, and positively skewed slight rightward.

Thus, data logarithmic transformation was applied to reduce the skewness and make the data almost to be closer to a normal distribution, (Figure 5).

Variograms of the data after transformation also showed a pure nugget effect and have a somewhat lower sill and range. The information derived from semivariograms, which abridged in Table 3 , is pointed out the reality of different spatial dependence for collected soil properties from the field and indicated that both SOC and SOC stock were best fitted to the exponential model. Nugget, range, and sill were equal to $0.002,0.036$, and 0.044 , respectively for SOC in topsoil, and $0.014,0.071$, and 0.081 , respectively for SOC in the subsoil. For SOC 
Table 3. The coefficient of the variogram models.

\begin{tabular}{|c|c|c|c|c|c|c|c|c|c|}
\hline Variab & & Method & Variogram & Model & Nugget & Range & Partial sill & Sill & Nugget/sill (\%) \\
\hline \multirow{4}{*}{ SOC $\%$} & \multirow{2}{*}{ Topsoil } & Ordinary Kriging & Semivariogram & Exponential & 0.002 & 0.036 & 0.044 & 0.046 & 4.3 \\
\hline & & Ordinary Kriging & Semivariogram & Spherical & 0.02 & 0.036 & 0.02 & 0.04 & 50 \\
\hline & \multirow{2}{*}{ Subsoil } & Ordinary Kriging & Semivariogram & Exponential & 0.014 & 0.071 & 0.067 & 0.081 & 17.2 \\
\hline & & Ordinary Kriging & Semivariogram & Spherical & 0.026 & 0.062 & 0.051 & 0.077 & 33.7 \\
\hline \multirow{4}{*}{$\mathrm{SOC} \mathrm{kg} / \mathrm{m}^{2}$} & \multirow{2}{*}{ Topsoil } & Ordinary Kriging & Semivariogram & Exponential & 0.0 & 0.036 & 0.508 & 0.508 & 0.0 \\
\hline & & Ordinary Kriging & Semivariogram & Spherical & 0.205 & 0.036 & 0.282 & 0.487 & 42 \\
\hline & \multirow{2}{*}{ Subsoil } & Ordinary Kriging & Semivariogram & Exponential & 0.1899 & 0.086 & 3.97 & 4.1599 & 4.5 \\
\hline & & Ordinary Kriging & Semivariogram & Spherical & 0.655 & 0.062 & 3.099 & 3.754 & 17.0 \\
\hline \multirow{4}{*}{ OC-SOC } & \multirow{2}{*}{ Topsoil } & Ordinary Cokriging & $\begin{array}{l}\text { Semivariogram; } \\
\text { Semivariogram }\end{array}$ & Exponential & 0.0 & 0.0365 & $\begin{array}{c}0.0475 ; 0.0930 \\
0.0930 ; 0.5085\end{array}$ & - & - \\
\hline & & Ordinary Cokriging & $\begin{array}{l}\text { Semivariogram; } \\
\text { Semivariogram }\end{array}$ & Spherical & $0.001 ; 0.0031$ & 0.0365 & $\begin{array}{c}0.0468 ; 0.0849 \\
0.0849 ; 0.5098\end{array}$ & - & - \\
\hline & \multirow{2}{*}{ Subsoil } & Ordinary Cokriging & $\begin{array}{l}\text { Semivariogram; } \\
\text { Semivariogram }\end{array}$ & Exponential & 0.0 & 0.07 & $\begin{array}{c}0.0916 ; 0.2350 \\
0.2350 ; 3.9105\end{array}$ & - & - \\
\hline & & Ordinary Cokriging & $\begin{array}{l}\text { Semivariogram; } \\
\text { Semivariogram }\end{array}$ & Spherical & $0.0208 ; 0.5841$ & 0.0573 & $\begin{array}{c}0.0625 ; 0.2859 \\
0.2859 ; 3.0605\end{array}$ & - & - \\
\hline
\end{tabular}

A1

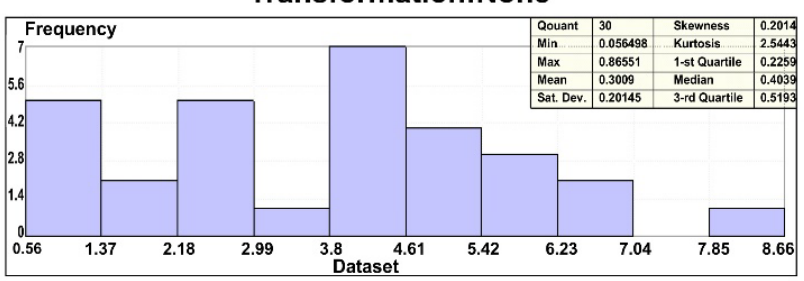

Dataset: Profiles attribute OC\%

B1

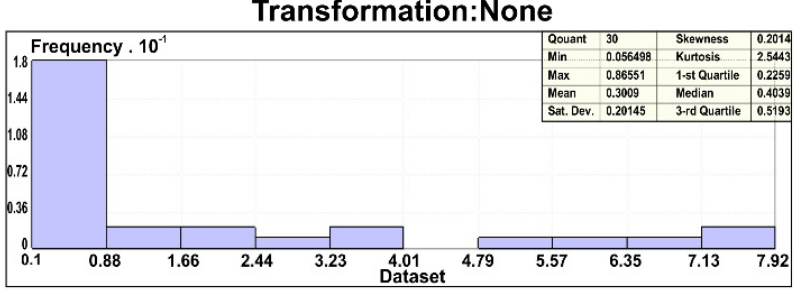

Dataset: Profiles attribute OC\%
A2 Histogram

Transformation:Log

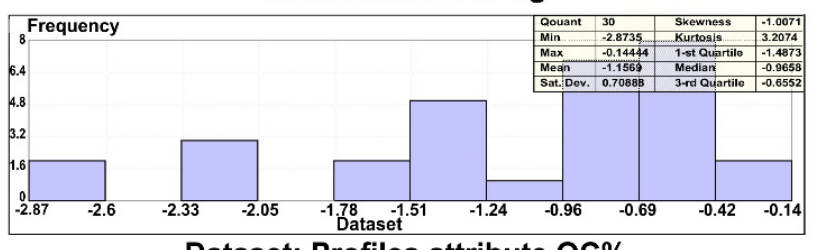

Dataset: Profiles attribute $\mathrm{OC} \%$

B2

Histogram

Transformation:None

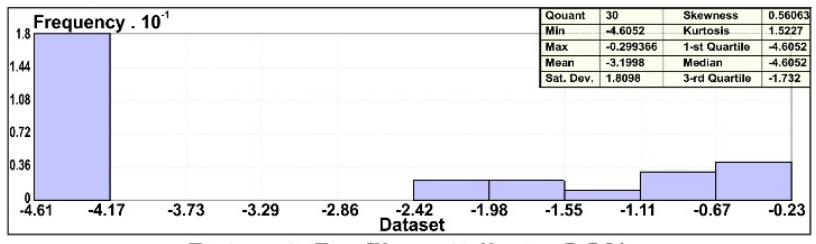

Dataset: Profiles attribute OC\%

Figure 5. Histograms of SOC Frequency distribution before transformation and after log transformation in topsoil (a) and subsoil (b), $(\mathrm{n}=30)$.

stock, it was $0.0,0.036$, and 0.0508 , respectively in topsoil, and $0.1899,0.086$, and 4.159 , respectively for in subsoil.

The semivariogram of the SOC indicated a slightly higher nugget effect in the subsoil than in the topsoil, implying a random and inherent variability, the similar suggestion for SOC stock. The sill values, representing total variation, showed a normal increasing trend from topsoil to subsoil for SOC, while the sit- 
uation was the opposite for SOC stock because the subsoil, in general, is thicker than topsoil.

The spatial dependencies that reflect the degree of autocorrelation between the sampling points; were 4.3 and 17.2 for SOC in topsoil and subsoil respectively, and 0.0 and 4.5 for SOCS in topsoil and subsoil respectively. The higher the spatial dependence between the samples points, the highest the spatial correlation, thus the data are shown a strong spatial dependence for SOC and SCO stock for both two layers, which can usually be attributed to intrinsic factors and for that the variables did not differ over short distances.

\section{Conclusion}

This study highlights the important contribution of semi-arid land in the eastern Mediterranean region in the global carbon cycle. In this study, considering SOM and SOC stock varying in both lateral and spatial directions, such variation can fallow systematic changes as a function of the microrelief, and/or soil management practices. The environmental conditions at Al Balikh plain as a semi-arid area are not favorable for organic matter developing and accumulation;, this is because of external factors (Climate, low precipitation, and hot dry summer) and internal factor (Geology, surface gypsic crest). These factors create abiotic stress that leads to low biomass forming. Moreover, organic carbon is more readily oxidize under hot, dry conditions, thus low carbon stock. Both SOC and SOC stocks were generally in the same level as those in other regions. The exception is that SOC was a little higher than these in the similar soils of the Euphrates region; this attributes to the area that is under intensive agriculture rotation for more than four-decades. It is clear to conclude that SOC stock mainly stores in the topsoil. The geostatistical analysis of the data indicates high systematic variability and low random variability. The spatial correlation was described using an exponential model, which was best fitted for data. A strong spatial dependence is shown for SOC and SCO stock within both two layers (topsoil, subsoil). Finally, the soils in arid and semi-arid areas have low organic matter content, a fragile structure, and coarse texture. Therefore, they are more sensitive than other soils to climate change, which can lead to accelerate loss of SOC stock, and a gradual deterioration in their quality and productivity.

\section{Acknowledgements}

The study was co-funded by the Alexander von Humboldt Foundation. Many thanks go to the Laboratory of Agricultural Scientific Research Center in Raqqa, Syria.

\section{Conflicts of Interest}

The authors declare no conflicts of interest regarding the publication of this paper. 


\section{References}

[1] Schimel, D.S. (1995) Terrestrial Ecosystems and the Carbon Cycle. Global Change Biology, 1, 77-91. https://doi.org/10.1111/j.1365-2486.1995.tb00008.x

[2] Lützow, M.V., Kögel-Knabner, I., Ekschmitt, K., Matzner, E., Guggenberger, G., Marschner, B. and Flessa, H. (2006) Stabilization of Organic Matter in Temperate Soils: Mechanisms and Their Relevance under Different Soil Conditions-A Review. European Journal of Soil Science, 57, 426-445. https://doi.org/10.1111/j.1365-2389.2006.00809.x

[3] Lal, R. (2008) Carbon Sequestration. Philosophical Transactions of the Royal Society of London B: Biological Sciences, 363, 815-830. https://doi.org/10.1098/rstb.2007.2185

[4] Oyonarte, C., Mingorance, M.D., Durante, P., Piñero, G. and Barahona, E. (2007) Indicators of Change in the Organic Matter in Arid Soils. Science of the Total Environment, 378, 133-137. https://doi.org/10.1016/j.scitotenv.2007.01.039

[5] Tarnocai, C., Canadell, J.G., Schuur, E.A.G., Kuhry, P., Mazhitova, G. and Zimov, S. (2009) Soil Organic Carbon Pools in the Northern Circumpolar Permafrost Region. Global Biogeochemical Cycles, 23, 1-11. https://doi.org/10.1029/2008GB003327

[6] Wang, Y., Huang, C., Sun, B., Quan, C., Wu, J. and Lin, Z. (2014) Paleo- $\mathrm{CO}_{2}$ Variation Trends and the Cretaceous Greenhouse Climate. Earth-Science Reviews, 129, 136-147. https://doi.org/10.1016/j.earscirev.2013.11.001

[7] Canada Department of Agriculture (1972) Glossary of Terms in Soil Science. Publication No. 1459, 66.

[8] Sparling, G.D. (1991) Organic Matter Carbon and Microbial Biomass Carbons Indicators of Sustainable Land Use. In: Elliot, C.R., Latham, M. and Dumanski, J., Eds., Evaluation for Sustainable and Management in the Developing World. Volume 2: Technical Papers, IBSRAM Proceedings No. 12. IBSRAM, Bangkok, Thailand.

[9] Swift, M.J. and Woomer, P. (1993) Organic Matter and Sustainability of Agricultural Systems: Definition and Measurement. In: Mulongoy, K. and Merckx, R., Eds., Soil Organic Matter Dynamics and Sustainability of Tropical Agriculture, John Wiley and Sons, New York, 3-18.

[10] Imeson, A.C. (1995) The Physical, Chemical and Biological Degradation of the Soil. In: Fantechi, R., Peter, D., Balabanis, P. and Rubio, J.L., Eds., Desertification in a European Context. Physical and Socio-Economic Aspects. Proceedings of the European School of Climatology and Natural Hazards Course, Alicante, 399-409.

[11] Stevenson, F.J. and Cole, M.A. (1999) Cycles of Soil. 2nd Edition, Wiley, New York.

[12] Stocking, M.A. (2003) Tropical Soils and Food Security: The Next 50 Years. Science, 302, 1356-1359. https://doi.org/10.1126/science.1088579

[13] Hartemink, A.E., Gerzabek, M.H., Lal, R. and McSweeney, K. (2014) Soil Carbon Research Priorities. In: Hartemink, A.E. and McSweeney, K., Eds., Soil Carbon, Springer, Cham, Switzerland, 483-490.

https://doi.org/10.1007/978-3-319-04084-4_48

[14] Herrick, J.E. and Wander, M.M. (1998) Relationships between Soil Organic Carbon and Soil Quality in Cropped and Rangeland Soils: The Importance of Distribution, Composition and Soil Biological Activity. In: Lal, R., Kimble, J., Follet, R. and Stewart, B.A., Eds., Advances in Soil Science, Taylor \& Francis Group, New York, 405-425. https://doi.org/10.1201/9780203739273-28

[15] von Lützow, M. and Kögel-Knabner, I. (2009) Temperature Sensitivity of Soil Or- 
ganic Matter Decomposition-What Do We Know? Biology and Fertility of Soils, 46, 1-15. https://doi.org/10.1007/s00374-009-0413-8

[16] Janssens, I.A., Dieleman, W., Luyssaert, S., Subke, J.A., Reichstein, M., Ceulemans, R., Ciais, P., Dolman, A.J., Grace, J., Matteucci, G., Papale, D., Piao, S.L., Schulze, E.D., Tang, J. and Law, B.E. (2010) Reduction of Forest Soil Respiration in Response to Nitrogen Deposition. Natural Geosciences, 3, 315-322.

https://doi.org/10.1038/ngeo844

[17] Fang, X., Xue, Z., Li, B. and An, S. (2012) Soil Organic Carbon Distribution in Relation to Land Use and Its Storage in a Small Watershed of the Loess Plateau, China. Catena, 88, 6-13. https://doi.org/10.1016/j.catena.2011.07.012

[18] Murphy, B. (2015) Key Soil Functional Properties Affected by Soil Organic Matter-Evidence from Published Literature. IOP Conference Series. Earth and Environmental Science, 25, Article ID: 12008. https://doi.org/10.1088/1755-1315/25/1/012008

[19] Batjes, N.H. (1996) Total Carbon and Nitrogen in the Soils of the World. European Journal of Soil Science, 47, 151-163. https://doi.org/10.1111/j.1365-2389.1996.tb01386.x

[20] Jobbágy, E.G. and Jackson, R.B. (2000) The Vertical Distribution of Soil Organic Carbon and Its Relation to Climate and Vegetation. Ecological Applications, 10, 423-436. https://doi.org/10.1890/1051-0761(2000)010[0423:TVDOSO]2.0.CO;2

[21] Harrison, R.B., Footen P.W., Strahm, B.D. (2011) Deep Soil Horizons: Contribution and Importance to Soil Carbon Pools and in Assessing Whole-Ecosystem Response to Management and Global Change. Forest Science, 57, 67-76.

[22] Jandl, R., Rodeghiero, M., Martinez, C., Cotrufo, M.F., Bampa, F., van Wesemael, B. and Lorenz, K. (2014) Current Status, Uncertainty and Future Needs in Soil Organic Carbon Monitoring. Science of the Total Environment, 468, 376-383. https://doi.org/10.1016/j.scitotenv.2013.08.026

[23] Minasny, B., McBratney, A.B., Malone, B.P. and Wheeler, I. (2013) Digital Mapping of Soil Carbon. Advances in Agronomy, 118, 1-47. https://doi.org/10.1016/B978-0-12-405942-9.00001-3

[24] Liski, J. and Westman, C.J. (1997) Carbon Storage in Forest Soil of Finland. 2. Size and Regional Pattern. Biogeochemistry, 36, 261-274. https://doi.org/10.1023/A:1005742523056

[25] United Nations Educational, Scientific and Cultural Organization (UNESCO) (1979) Map of the World Distribution of Arid Regions: Map at Scale 1:25,000,000 with Explanatory Note. MAB Technical Notes 7, UNESCO, Paris, 54.

[26] Lal, R. (2004) Soil Carbon Sequestration Impacts on Global Climate Change and Food Security. Science, 304, 1623-1627. https://doi.org/10.1126/science.1097396

[27] Lal, R. (2002) Soil Carbon Dynamics in Cropland and Rangeland. Environmental Pollution, 116, 353-362. https://doi.org/10.1016/S0269-7491(01)00211-1

[28] Klemmedson, J.O. (1989) Soil Organic Matter in Arid and Semiarid Ecosystems: Sources, Accumulation, and Distribution. Arid Land Research and Management, 3, 99-114. https://doi.org/10.1080/15324988909381194

[29] Lal, R. (2002) Carbon Sequestration in Dryland Ecosystems of West Asia and North Africa. Land Degradation \& Development, 13, 45-59. https://doi.org/10.1002/ldr.477

[30] Caravaca, F., Masciandaro, G. and Ceccanti, B. (2002) Land Use in Relation to Soil Chemical and Biochemical Properties in a Semiarid Mediterranean Environment. 
Soil and Tillage Research, 68, 23-30. https://doi.org/10.1016/S0167-1987(02)00080-6

[31] Komisarek, J., Hag Husein, H., Szałata, S. and Kozłowski, M. (2003) Spatial Variability of Soil Properties on Kame Field of the Poznań Lakeland. Roczniki Akademii Rolniczej. Melioracje i Inżynieria Środowiska, 24, 67-76.

http://yadda.icm.edu.pl/yadda/element/bwmeta1.element.agro-article-f82a5bc7-153 f-432d-96d5-07f05906a842

[32] Piccini, C., Marchetti, A. and Francaviglia, R. (2014) Estimation of Soil Organic Matter by Geostatistical Methods: Use of Auxiliary Information in Agricultural and Environmental Assessment. Ecological Indicators, 36, 301-314. https://doi.org/10.1016/j.ecolind.2013.08.009

[33] Meul, M. and Van Meirvenne, M. (2003) Kriging Soil Texture under Different Types of Nonstationarity. Geoderma, 112, 217-233. https://doi.org/10.1016/S0016-7061(02)00308-7

[34] Liu, D., Wang, Z., Zhang, B., Song, K., Li, X. and Li, J. (2006) Spatial Distribution of Soil Organic Carbon and Analysis of Related Factors in Croplands of the Black Soil Region, Northeast China. Agriculture, Ecosystems \& Environment, 113, 73-81. https://doi.org/10.1016/j.agee.2005.09.006

[35] Chai, X., Shen, C., Yuan, X. and Huang, Y. (2008) Spatial Prediction of Soil Organic Matter in the Presence of Different External Trends with REML-EBLUP. Geoderma, 148, 159-166. https://doi.org/10.1016/j.geoderma.2008.09.018

[36] Sumfleth, K. and Duttmann, R. (2008) Prediction of Soil Property Distribution in Paddy Soil Landscapes Using Terrain Data and Satellite Information as Indicators. Ecological Indicators, 8, 485-501. https://doi.org/10.1016/j.ecolind.2007.05.005

[37] Robinson, T.P. and Metternicht, G. (2006) Testing the Performance of Spatial Interpolation Techniques for Mapping Soil Properties. Computers and Electronics in Agriculture, 50, 97-108. https://doi.org/10.1016/j.compag.2005.07.003

[38] Burgess, T.M. and Webster, R. (1980) Optimal Interpolation and Isarithmic Mapping of Soil Properties. Journal of Soil Science, 31, 315-331. https://doi.org/10.1111/j.1365-2389.1980.tb02084.x

[39] Oliver, M.A. and Webster, R. (1991) How Geostatistics Can Help You. Soil Use and Management, 7, 206-217. https://doi.org/10.1111/j.1475-2743.1991.tb00876.x

[40] Kanevski, M. and Maignan, M. (2004) Analysis and Modelling of Spatial Environmental Data. EPFL Press, Lausanne.

[41] Duffera, M., White, J.G. and Weisz, R. (2007) Spatial Variability of Southeastern U.S. Coastal Plain Soil Physical Properties: Implications for Site-Specific Management. Geoderma, 137, 327-339. https://doi.org/10.1016/j.geoderma.2006.08.018

[42] Marchetti, A., Piccini, C., Francaviglia, R. and Mabit, L. (2012) Spatial Distribution of Soil Organic Matter Using Geostatistics: A Key Indicator to Assess Soil Degradation Status in Central Italy. Pedosphere, 22, 230-242. https://doi.org/10.1016/S1002-0160(12)60010-1

[43] Webster, R. and Oliver, M.A. (2001) Geostatistics for Environmental Scientists (Statistics in Practice). Wiley \& Sons Ltd., Chichester.

[44] McBratney, A.B., Malone, B.P. and Wheeler, I. (2013) Digital Mapping of Soil Carbon. Advances in Agronomy, 118, 1-47. https://doi.org/10.1016/B978-0-12-405942-9.00001-3

[45] Azawi, J., Hag Husein, H. and Mousa, M. (2014) Mapping Soil Fertility of Beer El-Hashem Project-Raqqa Using GIS. Research Journal of Aleppo University Agri- 
cultural Science Series, 107, 231-244.

[46] Alkhaier, F. (2003) Soil Salinity Detection Using Satellite Remote Sensing. Institute for Geo-Information Science and Earth Observation, Ensched, the Netherlands.

[47] Azawi, J., Hag Husein, H. and Mousa, M. (2014) Pedological, Physical and Chemical study of Some Soil Properties of Beer El-Hashem-Raqqa. Research Journal of Aleppo University Agricultural Science Series, 107, 19.

[48] Köppen, W. and Geiger, R. (1936) Das Geographische System der Klimate. In: Köppen, W. and Geiger, R., Eds., Handbuch der Klimatologie, Verlag Gebrüder Bornträger, Berlin (DE) (In German).

[49] Mulders, M.A. (1969) The Arid Soils of the Balikh Basin (Syria). Doctoral Dissertation, Bronder-Offset, Goudsesingel, 260.

[50] Technoexport (1966) The Geomorphological Map of Syria, Scale 1/500000. An Explanatory Note. Ministry of Industry, 111.

[51] Schrumpf, M., Schulze, E.D., Kaiser, K. and Schumacher, J. (2011) How Accurately Can Soil Organic Carbon Stocks and Stock Changes Be Quantified by Soil Inventories? Biogeosciences, 8, 1193-1212. https://doi.org/10.5194/bg-8-1193-2011

[52] Brasher, B.R., Franzmeier, D.P., Valassis, V. and Davidson, S.E. (1966) Use of Saran Resin to Coat Natural Soil Clods for Bulk-Density Water Retention Measurements. Soil Science, 101, 108. https://doi.org/10.1097/00010694-196602000-00006

[53] Nelson, D.W. and Sommers, L.E. (1982) Methods of Soil Analysis, Part 2. Chemical and Microbiological Properties. Agronomy Monograph, 9, 539-579.

[54] Sprengel, C. (1826) Ueber Pflanzenhumus, Humussaüre und humussaure Salze. Archiv für die Gesammte Naturlehre, 8, 145-220.

[55] FAO (2017) Soil Organic Carbon: The Hidden Potential. Food and Agriculture Organization of the United Nations, Rome, Italy.

[56] Huang, H.C. and Chen, C.S. (2007) Optimal Geostatistical Model Selection. Journal of the American Statistical Association, 102, 1009-1024.

https://doi.org/10.1198/016214507000000491

[57] Mishra, U., Lal, R., Slater, B., Calhoun, F., Liu, D. and Van Meirvenne, M. (2009) Predicting Soil Organic Carbon Stock Using Profile Depth Distribution Functions and Ordinary Kriging. Soil Science Society of America Journal, 73, 614-621. https://doi.org/10.2136/sssaj2007.0410

[58] Kumar, S., Lal, R. and Liu, D. (2012) A Geographically Weighted Regression Kriging Approach for Mapping Soil Organic Carbon Stock. Geoderma, 189, 627-634. https://doi.org/10.1016/j.geoderma.2012.05.022

[59] Khalil, M.I., Kiely, G., O’Brien, P. and Müller, C. (2013) Organic Carbon Stocks in Agricultural Soils in Ireland Using Combined Empirical and GIS Approaches. Geoderma, 193, 222-235. https://doi.org/10.1016/j.geoderma.2012.10.005

[60] Hengl, T. (2007) A Practical Guide to Geostatistical Mapping Ofenvironmental Variables European Commission, Joint Research Centre. Institute for Environment and Sustainability. Italy.

[61] Kerry, R. and Oliver, M.A. (2007) Comparing Sampling Needs for Variograms of Soil Properties Computed by the Method of Moments and Residual Maximum Likelihood. Geoderma, 140, 383-396. https://doi.org/10.1016/j.geoderma.2007.04.019

[62] Nayanaka, V.G.D., Vitharana, W.A.U. and Mapa, R.B. (2010) Geostatistical Analysis of Soil Properties to Support Spatial Sampling in a Paddy Growing Alfisol. Tropical Agricultural Research, 22, 34-44. https://doi.org/10.4038/tar.v22i1.2668

[63] Zhang, Z., Yu, D., Shi, X., Weindorf, D.C., Sun, W., Wang, H. and Zhao, Y. (2011) 
Effects of Prediction Methods for Detecting the Temporal Evolution of Soil Organic Carbon in the Hilly Red Soil Region, China. Environmental Earth Sciences, 64, 319-328. https://doi.org/10.1007/s12665-010-0849-z

[64] Mousavifard, S.M., Momtaz, H., Sepehr, E., Davatgar, N. and Sadaghiani, M.H.R. (2013) Determining and Mapping Some Soil Physico-Chemical Properties Using Geostatistical and GIS Techniques in the Naqade Region, Iran. Archives of Agronomy and Soil Science, 59, 1573-1589. https://doi.org/10.1080/03650340.2012.740556

[65] Varouchakis, E.A. and Hristopulos, D.T. (2013) Comparison of Stochastic and Deterministic Methods for Mapping Groundwater Level Spatial Variability in Sparsely Monitored Basins. Environmental Monitoring and Assessment, 185, 1-19. https://doi.org/10.1007/s10661-012-2527-y

[66] Venteris, E., Basta, N., Bigham, J. and Rea, R. (2014) Modeling Spatial Patterns in Soil Arsenic to Estimate Natural Baseline Concentrations. Journal of Environmental Quality, 43, 936-946. https://doi.org/10.2134/jeq2013.11.0459

[67] Tripathi, R., Nayak, A.K., Shahid, M., Raja, R., Panda, B.B., Mohanty, S. and Sahoo, R.N. (2015) Characterizing Spatial Variability of Soil Properties in Salt Affected Coastal India Using Geostatistics and Kriging. Arabian Journal of Geosciences, 8, 10693-10703. https://doi.org/10.1007/s12517-015-2003-4

[68] Bhunia, G.S., Shit, P.K. and Maiti, R. (2016) Comparison of GIS-Based Interpolation Methods for Spatial Distribution of Soil Organic Carbon (SOC). Journal of the Saudi Society of Agricultural Sciences, 17, 114-126. https://doi.org/10.1016/j.jssas.2016.02.001

[69] Warrick A.W., Myers, D.E. and Nielsen, D.R. (1986) Geostatistical Methods Applied to Soil Science. W: Methods of Soil Analysis, Part 1. Physical and Mineralogical Methods. Agronomy Monograph, 9, 53-82.

[70] Vauclin, M., Vieira, S.R., Vachaud, G. and Nielsen, D.R. (1983) The Use of Cokriging with Limited Field Soil Observations. Soil Science Society of America Journal, 47, 175-184. https://doi.org/10.2136/sssaj1983.03615995004700020001x

[71] Agrawal, O.P., Rao, K.V.G.K., Chauhan, H.S. and Khandelwal, M.K. (1995) Geostatistical Analysis of Soil Salinity Improvement with Subsurface Drainage System. Transactions of the ASAE, 38, 1427-1433. https://doi.org/10.13031/2013.27967

[72] Matheron, G. (1965) Les variables régionalisées et leur estimation: Une application de la théorie des fonctions aléatoires aux sciences de la nature. Masson et CIE.

[73] Nielsen, D.R. and Wendroth, O. (2003) Spatial and Temporal Statistics: Sampling Field Soils and Their Vegetation. Catena Verlag. GMBH, Reiskirchen, German, 398.

[74] Wang, Y.Q. and Shao, M.A. (2013) Spatial Variability of Soil Physical Properties in a Region of the Loess Plateau of PR China Subject to Wind and Water Erosion. Land Degradation \& Development, 24, 296-304. https://doi.org/10.1002/ldr.1128

[75] Trangmar, B.B., Yost, R.S. and Uehara, G. (1986) Application of Geostatistics to Spatial Studies of Soil Properties. Advances in Agronomy, 38, 45-94. https://doi.org/10.1016/S0065-2113(08)60673-2

[76] Robertson, G.P. (1987) Geostatistics in Ecology: Interpolating with Known Variance: Ecological Archives E068-003. Ecology, 68, 744-748. https://doi.org/10.2307/1938482

[77] Cambardella, C.A., Moorman, T.B., Novak, J.M., Parkin, T.B., Karlen, D.L., Turco, R.F. and Konopka, A.E. (1994) Field-Scale Variability of Soil Properties in Central Iowa Soils. Soil Science Society of America Journal, 58, 1501-1511. https://doi.org/10.2136/sssaj1994.03615995005800050033x 
[78] Al Siddik, M.A., Matar, A.E., Jones, M. and Shahine, M. (1992) The Cumulative of Long-Term Rotation and Nitrogen, Phosphate Fertilization on Soil Content of Organic Carbon, Total Nitrogen and C/N Ratio under Rainfed Cultivation in Northern Syria. Research Journal of Aleppo University Agricultural Sciences, 18, 125-151.

[79] Pillon, C.N. (2000) Stocks and Quality of Soil Organic Matter as Affected by No-Till Cropping System. Doctorate Thesis, Federal University of Rio Grande do Sul, Porto Alegre, 248.

[80] Murdock, L.W. and Frye, W.W. (1985) Erosion: Its Effect on Soil Properties, Productivity and Profit. Publication AGR-102. College of Agriculture, University of Kentucky, Lexington, KY.

[81] Liu, Z.P., Shao, M.A. and Wang, Y.Q. (2012) Large-Scale Spatial Variability and Distribution of Soil Organic Carbon across the Entire Loess Plateau, China. Soil Research, 50, 114-124. https://doi.org/10.1071/SR11183

[82] Marland, G. and Schlamadinger, B. (1999) The Kyoto Protocol Could Make a Difference for the Optimal Forest-Based $\mathrm{CO}_{2}$ Mitigation Strategy: Some Results from GORCAM. Environmental Science and Policy, 2, 111-124.

https://doi.org/10.1016/S1462-9011(99)00008-8

[83] Zibilske, L.M., Bradford, J.M. and Smart, J.R. (2002) Conservation Tillage Induced Changes in Organic Carbon, Total Nitrogen and Available Phosphorus in a Semiarid Alkaline Subtropical Soil. Soil and Tillage Research, 66, 153-163. https://doi.org/10.1016/S0167-1987(02)00023-5

[84] Burle, M.L., Mielniczuk, J. and Focchi, S. (2005) Effect of Cropping Systems on Soil Chemical Characteristics, with Emphasis on Soil Acidification. Plant \& Soil, 190, 309-316. https://doi.org/10.1023/A:1004266831343 